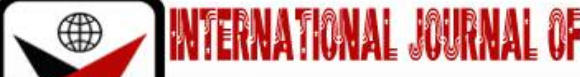

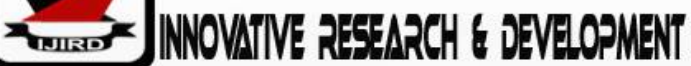

ISSN 2278-0211 (Online)

\section{Analysis of the Influence of Field Trips on the Effective Teaching and Learning of Business Studies in Junior Secondary Schools in Kwara State of Western Nigeria}

\begin{tabular}{c} 
Ayanwole Ayanyemi Adeyemi \\
Senior Lecturer, Department of Business Education \\
Michael Otedola College of Primary Education Noforija Epe Lagos State, Nigeria \\
Olanrewaju Tolulope Azeez \\
Lecturer, Department of Business Education \\
Michael Otedola College of Primary Education Noforija Epe Lagos State, Nigeria \\
\hline
\end{tabular}

\begin{abstract}
:
This study assessed the influence of field trips on effective teaching and learning of business studies in junior secondary schools in Kwara State. The purpose of the study is to determine, if the field trips as supplementary method of teaching will enhance the effective teaching and learning of business studies in Junior Secondary Schools in Offa and Oyun Local Government Area of Kwara State, the perception of teachers and students on the use of field trip as a supplementary method in teaching and learning of business studies and the difference between the academic performance of students in the schools where teachers use field trips and those where their teachers do not use field trips. Subjects for the study comprised one hundred and sixty (160) students offering business studies and sixteen (16) teachers, teaching business studies from eight (8) junior secondary schools. Data for the study were gathered through the administration of questionnaire and collection of scores of J.S.S. III National Junior Secondary School Examination for 2012, 2013 and 2014 respectively. The data collected were analyzed, using mean and standard deviation to answer the research questions while the t-test statistical technique was used to test the hypotheses at 0.05 level of significance. The result obtained from the analyzes showed that the use of field trips as a supplementary method of teaching will enhance the effective teaching and learning of business studies in junior secondary schools. On the basis of these findings, some recommendations were made that teachers of secondary schools should be encouraged to use field trips as instructional resources to enhance the teaching and learning of business studies, teaching time table should be planned by the school authorities such that they make room for the organization of field trips to promote effective teaching and learning, the teacher education programme should be geared towards the preparation of business studies teachers that will enable them to acquire and maintain appropriate instructional strategy, curriculum planners should formulate policies on the field trips in the teaching of business studies, so that the decision to utilize field trips is not left to the personal discretion of any single individual or individuals and Government though the ministry of education should set aside some founds to support the organization of field trips to enhance effective teaching and learning.
\end{abstract}

Keywords: Business studies, field trip, methods of teaching, perception

\section{Introduction}

Business studies is one of the numerous subjects that yields it to field trips, it is basically taken at the Junior Secondary School Level. Subjects such as book-keeping/accounting, shorthand, typewriting, office practice, commerce and economics are taught at the Junior secondary School under Business Studies. Business Studies is Vocational in Nature and aims at the inculcation and acquisition of functional knowledge, skills, attitude and competencies needed to function economically in the society. Among the objectives that are to be inculcated at an early age are those worthwhile values that are required for an entrepreneur and employees to succeed in the business environment. Consequently, from the curriculum content of business studies it is mostly assumed that some of the subjects are practical in nature and are required to be taught practically by making the teaching situation as real as possible. From observation however, indications are that the subject is mostly theoretically taught in Junior Secondary Schools. In order to complement the theoretical component, field trips must be introduced to give reality to the subject taught while it will enhance the grasp of the subject matter and enhance the students' academic performance. The teaching and learning of Business Studies will be more interesting, involving and captivating when it is actively taught and the teaching is learner's centered. In addition, business studies teaching emphasizes authentic activities that call for real life application using the skill and content of the field. Take for example in a business subject, if the teacher want to teach a topic under Office Practice with the Topic "Handling Office Equipment", it will very much assist the learner (s) if the teacher would take time to take the students out 
of the classroom to industries or a corporate business organization where those equipment can be can be observed and seen physically by the students. Therefore, there is need to supplement the classroom theoretical aspect with practical sessions such as Field Trip in order to enhance students' academic performance.

Field Trip is an effective means of supplementing classroom teaching for better result. It involves taking the students out of the classroom to places where they can see concrete illustration of classroom theories. As such the main task of the business studies teacher is to ensure that students understand and make meaning out of whatever they learn in class. Hence this depends on the experience, training as well as the teachers' perception of what business studies is or ought to be.

Effective Teaching and Learning in Junior Secondary School is a major concern in many countries of the world. For effective teaching and learning to take place, we need torch lighter teachers who distinguish themselves and set themselves apart from the rest. It argued that effective teaching and learning also take place where there is reflective practice. Reflective practices are considered as the brick and motor for effective teaching and learning

\section{Conceptual Clarifications}

\subsection{Field Trip}

Jekayinfa (2005) asserts that Field Trips are usually planned to take students not only to places of interest but also to places where relevant materials, information or knowledge are available for better teaching and learning of a particular subject matter. Field Trips have long been used as a context for teaching and learning in business studies. Field Trips can provide students the opportunity to construct knowledge through interacting with business places, experts and artifacts. When integrated into the curriculum, Field Trips can be among the valuable and effective modes of teaching. Colonial Williamsburg conceptualized on virtual field trips theory for educational researchers. The current virtual field trips model by Colonial Williamsburg was selected after an extensive examination of available and commonly utilized virtual field trips identified through a search of the business studies professional literature and online resource lists. This virtual trip model includes multiple ways for students to participate in the teaching and learning process through the field trips, it includes all the element of criteria needed for selection of field trip.

Fig. 1 Illustration of a conceptual model that incorporates the characteristics for a successful virtual field trips tagged VFT model, for if these models are used systematically, they will engage students in authentic and effective learning experience.

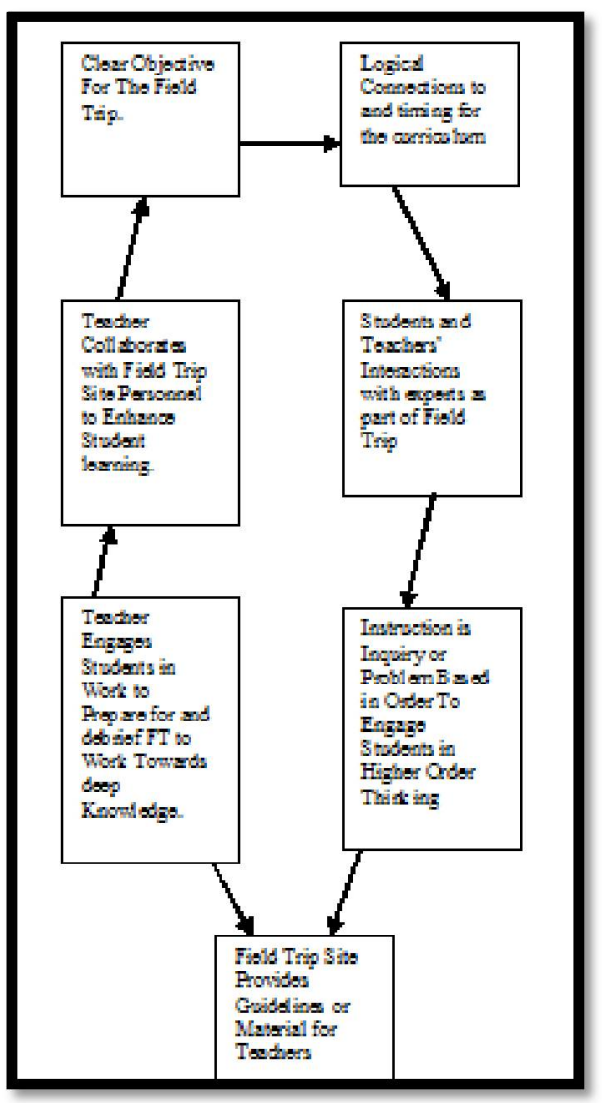

Figure 1: A Conceptual Model of Virtual Field Trips on Authentic Business Studies Source: Adapted from Virtual Field Trips on Authentic Business Studies [Colonial Williamsburg 1999]

\subsection{Effective Teaching and Learning}

Effective teaching and learning are considered as a mystery by some authors (Guidhaber, 2002). In a study on conception of effective teaching and learning, Saroyan (2009) found out that students expressed four ideas about effective teaching and learning. Effective teacher(s) have knowledge, prepare and manage instructions, promote learning and help 
students grow so that they can learn independently. The effective teacher exhibits passion for their subjects, are knowledgeable about and care for students, use a variety of teaching method and help students appreciate the relevance of information to their own content. Sprinkle (2009) studied students' perception of effective teaching and learning and found out that students considered effective teachers as those who employ a variety of teaching styles and make real world applications. Effective teacher however, exhibit humor, enthusiasm, compassion, empathy, and are interested in and concerned for students outside the classroom. Pietrzak, Duncan \& Korcuska (2008) found effective teachers to possess a degree of knowledge, effective delivery style, organization and known for the amount of assigned home work.

\subsection{Methods of Teaching Business Studies}

One of the utmost goals and roles of a trained teacher is to impact knowledge, values, attitude and skills into the lives of learners, so as to bring about a positive change. A positive change is expected to make the learner to be more useful to himself and the society at large, through successful and effective teaching and learning processes. For effective teaching to take place, a good method of teaching must be adopted by a teacher. But when deciding what teaching method to use, a teacher needs to consider students background of knowledge, environment and learning goals. It is noteworthy, that there is no single method or teaching that can solely attain the desired goals. This is the reason why teachers often apply techniques, with multiple learning styles to help students retain information and strengthen understanding.

As a business subject teacher, there are many methods and techniques of teaching that a teacher employs effectively and efficiently in presenting his lesson to the students to achieve already desired goals. The following are the most popular methods that can be adopted in teaching business studies as well as other subjects:

- Lecture Method: This can be described as one of the popular and mostly used method of teaching. It is a one-way means of communication in the classroom where the teacher does the teaching and students listen.

- Discussion Method: This is a method of teaching where the teacher allows students to participate democratically and positively in the classroom by contributing their own ideas in the subject matter

- Questioning Method or Socratic Method: This is an important part of guiding students learning when students ask questions, they are often seeking to shorten the learning process by getting the right answer from their teacher and vice-versa. Adeniyi, Ajobiewe and Adejumobi (2008) describe questioning method as an approach where the teacher delivers his lessons through series of questions.

- Demonstration Method: This is usually used by teachers to illustrate and demonstrate a procedure to be followed. Ndimechi (1990) agreed that for subjects like Typewriting, Office practice, Shorthand and Salesmanship, the teachers' demonstration by all means is most important. The teacher's demonstration shows the students the various manipulations of the machines which include:

- Role Playing or Drama Method: This can be described as acting the role of another person. Uzoma (1994) state that it is a method of teaching where students are made to act out certain roles in the class like the roles of Secretaries, Receptionists and the part played by the executives in taking decisions concerning management problems and situations. Hence other methods of teaching business studies include the following: Problem Solving Method, Programmed Instruction Method, Cooperative Learning and Buzz Session, Use of Power Point Slides, Practice Drill and Play-Way Method.

\section{Statement of the Problem}

During field work is business studies, a learner does not only acquire cognitive and psychomotor skills but also the affective skills as skill as well. The acquisition of the affective skill is needed to foster the attitudinal change among learners which takes a long time to develop and must not be left to chance and it must not be seen as an activity which occur out of serendipity. On the account of this there is the need on the part of business studies teachers to plan and use Field Trips in the teaching and learning process bearing in mind the essence of continuity and sequence to foster reiteration and widening of scope as well as catering for the depth of affective element to acquire.

\subsection{Purpose of the Study}

- To examine the perception of teachers and students on the use of field trip as a supplementary method in teaching and learning of business studies.

- To examine the difference between the academic performances of students in the schools where teachers use field trips as a supplementary teaching method and those where their teachers do not use field trips as a supplementary teaching method.

- To examine the number of schools which business studies teachers use field trips to complement their business studies instructions.

\subsection{Research Questions}

For the purpose of this study, the following research questions were formulated to guide the study:

- Does filed trip influence the effective teaching and learning of business studies in Junior Secondary schools in Offa and Oyun Local Government Area of Kwara State in Western Nigeria?

- What are the perceptions of students and teachers on the use of field trips as a supplementary method of teaching and learning business studies?

- What is the difference between the academic performance of students whose teachers use field trips to complement their method of teaching business studies and those whose teachers do not? 
- How many schools do their business studies teachers use filed trips as a supplementary method in teaching and learning business studies?

\subsection{Formulated Hypotheses}

- H01: The mean response of teachers and students have no influence on the effectiveness of using field trip exercise as a supplementary method of teaching and learning business studies.

- H02: The mean response of students has no influence on field trip exercise as a supplementary method of teaching by those whose teachers use field trips and those whose teachers do not.

\section{Methodology}

The researcher administered the questionnaire to the respondents with the assistance of two trained research assistants each from one Local Government Area of the (Oyun and Offa Local government of Kwara State in Western Nigeria). The exercise lasted two weeks. Similarly, the researcher collected the scores of J.S.S III National Junior Secondary School Examination for the year 2012, 2013 and 2014 from Kwara Ministry of Education and Human Capital Development

\subsection{Data Analysis}

The data collected on the analysis of the influence of field trips exercise on the effective teaching and learning of business studies in junior secondary schools, research questions were analyzed using simple percentage, mean, standard deviation and t-test. Mean was used to analyze data in order to answer the research questions. The decision rule was based on mean ranking of each item in order to compare item by item in relation to the research questions of the study. Additionally, a cut-off point of 2.50 was considered such that any item with the mean less than 2.50 was regarded as disagreed, otherwise it was regarded as agreed. For the test of hypotheses, t-test was employed at 0.05 level of significance. The decision rule was based on comparing the probability value and the alpha value (0.05). If the probability value (P-Value) is less than the alpha value at 0.05 level of significance, it was rejected or otherwise was retained.

\section{Empirical Result and Findings}

\subsection{Analysis of Bio-Data}

The bio-data is analysed using simple percentage and presented

\begin{tabular}{|c|c|c|c|}
\hline Field Trip Status & No. of Schools & Frequency & Percentage \\
\hline Utilize Field Trips & 4 & 88 & 50.0 \\
\hline Without Field Trips & 4 & 88 & 50.0 \\
\hline Total & 8 & 176 & 100.0 \\
\hline
\end{tabular}

Table 1: Fieldtrip Status of the Selected Schools

Source: Field Study, 2016

Form the eight (8) schools elected, four (4) schools utilizes field trips as supplementary method for teaching and learning of Business Studies while four (4) schools do not.

\subsection{Answering of Research Questions}

The data analysis for the research questions was done using mean and standard deviation. The results are presented in table 8 to 16 . Mean scores were obtained from the scoring of the instrument ( $S A=4 ; A=3 ; D=2 ; S D=1) ;$ which gives an average of 2.5. This implies that mean scores of 2.5 above are classified as "agreed" while those below 2.5 are regarded as disagreed.

\subsubsection{Research Question One}

Does filed trip influence the effective teaching and learning of business studies in Junior Secondary schools in Offa and Oyun Local Government Area of Kwara State in Western Nigeria? 


\begin{tabular}{|c|c|c|c|c|c|c|c|c|}
\hline $\mathbf{S} / \mathbf{N}$ & Items Statement & SD & D & A & SA & Mean & $\begin{array}{l}\text { Std. } \\
\text { Dev }\end{array}$ & $\begin{array}{c}\text { Ran } \\
\mathbf{k}\end{array}$ \\
\hline 1 & $\begin{array}{l}\text { The use of field trips as } \\
\text { supplementary method } \\
\text { of teaching business } \\
\text { studies } \\
\text { learners }\end{array}$ & $\begin{array}{c}1 \\
(0.6 \%)\end{array}$ & $\begin{array}{c}5 \\
(2.8 \%)\end{array}$ & $\begin{array}{c}72 \\
(40.9 \%)\end{array}$ & $\begin{array}{c}98 \\
(55.7 \%)\end{array}$ & 3.52 & .585 & $1^{\text {st }}$ \\
\hline 2 & $\begin{array}{l}\text { The use of field trips as } \\
\text { complementary } \\
\text { method of teaching } \\
\text { business studies allow } \\
\text { the students to fully } \\
\text { participate in the } \\
\text { process of teaching and } \\
\text { learning }\end{array}$ & $\begin{array}{c}2 \\
(1.1 \%)\end{array}$ & $\begin{array}{c}8 \\
(4.5 \%)\end{array}$ & $\begin{array}{c}83 \\
(47.2 \%)\end{array}$ & $\begin{array}{c}83 \\
(47.2 \%)\end{array}$ & 3.40 & .634 & $2^{\text {nd }}$ \\
\hline 3 & $\begin{array}{l}\text { The use of field trips } \\
\text { enhances team work in } \\
\text { teaching business } \\
\text { studies }\end{array}$ & $\begin{array}{c}3 \\
(1.7 \%)\end{array}$ & $\begin{array}{c}22 \\
(12.5 \%)\end{array}$ & $\begin{array}{c}87 \\
(49.4 \%)\end{array}$ & $\begin{array}{c}64 \\
(36.4 \%)\end{array}$ & 3.20 & .720 & $5^{\text {th }}$ \\
\hline 4 & $\begin{array}{l}\text { The use of field trips } \\
\text { added more knowledge } \\
\text { to and thereby enhance } \\
\text { effective teaching and } \\
\text { learning }\end{array}$ & $\begin{array}{c}4 \\
(2.3 \%)\end{array}$ & $\begin{array}{c}12 \\
(6.8 \%)\end{array}$ & $\begin{array}{c}70 \\
(39.8 \%)\end{array}$ & $\begin{array}{c}90 \\
(51.1 \%)\end{array}$ & 3.40 & .718 & $2^{\text {nd }}$ \\
\hline 5 & $\begin{array}{l}\text { The use of field trips } \\
\text { allows students to } \\
\text { relate with an expert } \\
\text { therefore enhance } \\
\text { effective teaching and } \\
\text { learning business } \\
\text { studies }\end{array}$ & $\begin{array}{c}8 \\
(4.5 \%)\end{array}$ & $\begin{array}{c}8 \\
(4.5 \%)\end{array}$ & $\begin{array}{c}73 \\
(41.5 \%)\end{array}$ & $\begin{array}{c}87 \\
(49.4 \%)\end{array}$ & 3.36 & .773 & $4^{\text {th }}$ \\
\hline 6 & $\begin{array}{l}\text { Students are able to } \\
\text { see, feel, touch the } \\
\text { objects taught in the } \\
\text { classroom through the } \\
\text { use of field trips which } \\
\text { enhances the effective } \\
\text { teaching and learning } \\
\text { of business studies }\end{array}$ & $\begin{array}{c}13 \\
(7.4 \%)\end{array}$ & $\begin{array}{c}9 \\
(5.1 \%)\end{array}$ & $\begin{array}{c}91 \\
(51.7 \%)\end{array}$ & $\begin{array}{c}63 \\
(35.8 \%)\end{array}$ & 3.16 & .827 & $7^{\text {th }}$ \\
\hline 7 & $\begin{array}{l}\text { Students are able to } \\
\text { relate with other } \\
\text { students from other } \\
\text { schools through the use } \\
\text { of field trips which } \\
\text { enhances effective } \\
\text { teaching and learning } \\
\text { of business studies }\end{array}$ & $\begin{array}{c}13 \\
(7.4 \%)\end{array}$ & $\begin{array}{c}13 \\
(7.4 \%)\end{array}$ & $\begin{array}{c}76 \\
(43.2 \%)\end{array}$ & $\begin{array}{c}74 \\
(42.0 \%)\end{array}$ & 3.20 & .869 & $5^{\text {th }}$ \\
\hline 8 & $\begin{array}{l}\text { Large number of } \\
\text { students in a classroom } \\
\text { does not allow field } \\
\text { trips as supplementary } \\
\text { method for teaching } \\
\text { business studies to be } \\
\text { effective }\end{array}$ & $\begin{array}{c}25 \\
(14.2 \%)\end{array}$ & $\begin{array}{c}51 \\
(29.0 \%)\end{array}$ & $\begin{array}{c}62 \\
(35.2 \%)\end{array}$ & $\begin{array}{c}38 \\
(21.6 \%)\end{array}$ & 2.64 & .975 & $8^{\text {th }}$ \\
\hline
\end{tabular}

Table 2: Mean and Standard Deviation of Whether Field Trips Enhance

Effective Teaching and Learning of Business Studies in Junior Secondary Schools

Source: Field Study, 2016

The data presented in table 8 shows the respondents' (teachers and students) opinion on whether Field Trips enhance effective teaching and learning of Business Studies. The items were expressed in frequencies and percentages and also in means and standard deviation. The mean responses were used to determine the ranks of the items in terms of their priority and importance. Items 1, 2 and 4 ranked 1st and 2nd respectively, while item8 ranked 8thwith mean score of 2.64. On the average, items 1-7 have means well above 3.0 which signifies high level of agreement with the items, only item 8 have a mean score of 2.6 which has an almost balanced agreement and disagreement levels. This means that respondents 
are more of the opinion that "the use of field trips as supplementary method of teaching business studies motivates learners"; also "the use of field trips as complementary method of teaching business studies allow the students to fully participate in the process of teaching and learning" and that "the use of field trips added more knowledge to and thereby enhance effective teaching and learning". On the other hand, respondents were almost undecided on whether "large number of students in a classroom does not allow field trips as supplementary method for teaching business studies to be effective ".

\subsubsection{Research Question Two}

What are the perceptions of students and teachers on the use of field trips as a supplementary method of teaching and learning business studies.

\begin{tabular}{|c|c|c|c|c|c|c|c|c|}
\hline $\mathbf{S} / \mathbf{N}$ & Items Statements & SD & D & $\mathbf{A}$ & SA & Mean & $\begin{array}{l}\text { Std. } \\
\text { Dev }\end{array}$ & Rank \\
\hline 1 & $\begin{array}{l}\text { Students have negative } \\
\text { attitude towards the use of } \\
\text { field trips as supplementary } \\
\text { method of teaching } \\
\text { business studies }\end{array}$ & $\begin{array}{c}41 \\
(23.3 \%)\end{array}$ & $\begin{array}{c}59 \\
(33.5 \%)\end{array}$ & $\begin{array}{c}47 \\
(26.7 \%)\end{array}$ & $\begin{array}{c}29 \\
(16.5 \%)\end{array}$ & 2.36 & 1.016 & $7^{\text {th }}$ \\
\hline 2 & $\begin{array}{l}\text { Economic background of } \\
\text { the students has an adverse } \\
\text { effect on the use of field } \\
\text { trips as supplementary } \\
\text { method of teaching } \\
\text { business studies }\end{array}$ & $\begin{array}{c}8 \\
(4.5 \%)\end{array}$ & $\begin{array}{c}34 \\
(19.3 \%)\end{array}$ & $\begin{array}{c}75 \\
(42.6 \%)\end{array}$ & $\begin{array}{c}59 \\
(33.5 \%)\end{array}$ & 3.05 & .844 & $2^{\text {nd }}$ \\
\hline 3 & $\begin{array}{l}\text { The use of field trips in the } \\
\text { process of teaching and } \\
\text { learning of business studies } \\
\text { improve academic } \\
\text { performance of the } \\
\text { students }\end{array}$ & $\begin{array}{c}1 \\
(0.6 \%)\end{array}$ & $\begin{array}{c}7 \\
(4.0 \%)\end{array}$ & $\begin{array}{c}79 \\
(44.9 \%)\end{array}$ & $\begin{array}{c}89 \\
(50.6 \%)\end{array}$ & 3.45 & .603 & $1^{\text {st }}$ \\
\hline 4 & $\begin{array}{l}\text { Means of transportation } \\
\text { discourage most of the } \\
\text { teachers in using field trips } \\
\text { as supplementary method } \\
\text { of teaching and learning of } \\
\text { business studies }\end{array}$ & $\begin{array}{c}20 \\
(11.4 \%)\end{array}$ & $\begin{array}{c}36 \\
(20.5 \%)\end{array}$ & $\begin{array}{c}84 \\
(47.7 \%)\end{array}$ & $\begin{array}{c}36 \\
(20.5 \%)\end{array}$ & 2.77 & .904 & $5^{\text {th }}$ \\
\hline 5 & $\begin{array}{l}\text { There is no adequate } \\
\text { support from the principals } \\
\text { of the school in using field } \\
\text { trips as a supplementary } \\
\text { method of teaching } \\
\text { business studies }\end{array}$ & $\begin{array}{c}36 \\
(20.5 \%)\end{array}$ & $\begin{array}{c}61 \\
(34.7 \%)\end{array}$ & $\begin{array}{c}46 \\
(26.1 \%)\end{array}$ & $\begin{array}{c}33 \\
(18.8 \%)\end{array}$ & 2.43 & 1.018 & $6^{\text {th }}$ \\
\hline 6 & $\begin{array}{l}\text { Fear of parent towards the } \\
\text { release of their children has } \\
\text { an adverse effect on the use } \\
\text { of field trips as a } \\
\text { supplementary method of } \\
\text { teaching business studies }\end{array}$ & $\begin{array}{c}16 \\
(9.1 \%)\end{array}$ & $\begin{array}{c}38 \\
(21.6 \%)\end{array}$ & $\begin{array}{c}73 \\
(41.5 \%)\end{array}$ & $\begin{array}{c}49 \\
(27.8 \%)\end{array}$ & 2.88 & .921 & $3^{\text {rd }}$ \\
\hline 7 & $\begin{array}{l}\text { Students' background and } \\
\text { environment do not } \\
\text { stimulate teachers in the } \\
\text { using trips as a } \\
\text { supplementary method in } \\
\text { teaching business studies }\end{array}$ & $\begin{array}{c}14 \\
(8.0 \%)\end{array}$ & $\begin{array}{c}36 \\
(20.5 \%)\end{array}$ & $\begin{array}{c}86 \\
(48.8 \%)\end{array}$ & $\begin{array}{c}40 \\
(22.7) \%\end{array}$ & 2.86 & 858 & $4^{\text {th }}$ \\
\hline
\end{tabular}

Table 3: Mean and Standard Deviation on the Perceptions of Students and Teachers on the Use of Field Trips as a Supplementary Method of Teaching and Learning of Business Studies

Source: Field Study, 2016

Table 3 above shows the perceptions of students and teachers on the use of field trips as a supplementary method of teaching and learning of business studies. The respondents perceived that "the use of field trips in the process of teaching and learning of business studies improve academic performance of the students" and "economic background of the students has an adverse effect on the use of field trips as supplementary method of teaching business studies". The items 3 and 2 ranked 1st and 2nd with mean score of 3.45 and 3.05 respectively. On the other hand, the respondents disagreed on statements that "students have negative attitude towards the use of field trips as supplementary method of 
teaching business studies" and that "there is no adequate support from the principals of the school in using field trips as a supplementary method of teaching business studies", which ranked 7th and 6th with mean scores of 2.36 and 2.43 respectively.

\begin{tabular}{|c|c|c|c|c|c|}
\hline $\mathbf{S} / \mathbf{N}$ & Items & $\mathbf{N}$ & Mean & Std. Dev. & Rank \\
\hline 1 & $\begin{array}{l}\text { Students have negative } \\
\text { attitude towards the use of } \\
\text { field trips as supplementary } \\
\text { method of teaching business } \\
\text { studies }\end{array}$ & 16 & 2.37 & 1.088 & $7^{\text {th }}$ \\
\hline 2 & $\begin{array}{l}\text { Economic background of the } \\
\text { students has an adverse } \\
\text { effect on the use of field } \\
\text { trips as supplementary } \\
\text { method of teaching business } \\
\text { studies }\end{array}$ & 16 & 3.31 & .704 & $3^{\text {rd }}$ \\
\hline 3 & $\begin{array}{l}\text { The use of field trips in the } \\
\text { process of teaching and } \\
\text { learning of business studies } \\
\text { improver academic } \\
\text { performance of the students }\end{array}$ & 16 & 3.44 & .727 & 1 st \\
\hline 4 & $\begin{array}{l}\text { Means of transportation } \\
\text { discourage most of the } \\
\text { teachers in using field trips } \\
\text { as supplementary method of } \\
\text { teaching and learning of } \\
\text { business studies }\end{array}$ & 16 & 3.00 & .966 & $5^{\text {th }}$ \\
\hline 5 & $\begin{array}{l}\text { There is no adequate } \\
\text { support from the principals } \\
\text { of the school in using field } \\
\text { trips as a supplementary } \\
\text { method of teaching business } \\
\text { studies }\end{array}$ & 16 & 2.88 & 1.147 & $6^{\text {th }}$ \\
\hline 6 & $\begin{array}{l}\text { Fear of parent towards the } \\
\text { release of their children has } \\
\text { an adverse effect on the use } \\
\text { of field trips as a } \\
\text { supplementary method of } \\
\text { teaching business studies }\end{array}$ & 16 & 3.31 & .793 & $3^{\mathrm{rd}}$ \\
\hline 7 & $\begin{array}{l}\text { Students' background and } \\
\text { environment do not } \\
\text { stimulate teachers in the } \\
\text { using trips as a } \\
\text { supplementary method in } \\
\text { teaching business studies }\end{array}$ & 16 & 3.38 & .957 & $2^{\text {nd }}$ \\
\hline
\end{tabular}

Table 4: Mean and Standard Deviation and Rank Order Analysis of Teachers' Perception on the Use of Field Trips as a Supplementary Method of Teaching and Learning of Business Studies Source: Field Study, 2016

\begin{tabular}{|c|c|c|c|c|c|}
\hline $\mathbf{S} / \mathbf{N}$ & Items & $\mathbf{N}$ & Mean & Std. Dev & Rank \\
\hline 1 & $\begin{array}{c}\text { Students have negative attitude } \\
\text { towards the use of field trips as } \\
\text { supplementary method of teaching } \\
\text { business studies }\end{array}$ & 160 & 2.36 & 1.012 & $7^{\text {th }}$ \\
\hline 2 & $\begin{array}{c}\text { Economic background of the students } \\
\text { has an adverse effect on the use of } \\
\text { field trips as supplementary method } \\
\text { of teaching business studies }\end{array}$ & 160 & 3.03 & .854 & $2^{\text {nd }}$ \\
\hline 3 & $\begin{array}{c}\text { The use of field trips in the process of } \\
\text { teaching and learning of business } \\
\text { studies improve academic } \\
\text { performance of the students }\end{array}$ & 160 & 3.46 & .592 & $1^{\text {st }}$ \\
\hline
\end{tabular}




\begin{tabular}{|c|c|c|c|c|c|}
\hline $\mathbf{S} / \mathbf{N}$ & \multicolumn{1}{c|}{ Items } & $\mathbf{N}$ & Mean & Std. Dev & Rank \\
\hline 4 & $\begin{array}{c}\text { Means of transportation discourage } \\
\text { most of the teachers in using field } \\
\text { trips as supplementary method of } \\
\text { teaching and learning of business } \\
\text { studies }\end{array}$ & 160 & 2.75 & .897 & $5^{\text {th }}$ \\
\hline 5 & $\begin{array}{c}\text { There is no adequate support from } \\
\text { the principals of the school in using } \\
\text { field trips as a supplementary } \\
\text { method of teaching business studies }\end{array}$ & 160 & 2.39 & .997 & $6^{\text {th }}$ \\
\hline 6 & $\begin{array}{c}\text { Fear of parent towards the release of } \\
\text { their children has an adverse effect } \\
\text { on the use of field trips as a } \\
\text { supplementary method of teaching } \\
\text { business studies }\end{array}$ & 160 & 2.84 & .924 & $3^{\text {rd }}$ \\
\hline 7 & $\begin{array}{c}\text { Students' background and } \\
\text { environment do not stimulate } \\
\text { teachers in the using trips as a } \\
\text { supplementary method in teaching } \\
\text { business studies }\end{array}$ & 160 & 2.81 & .833 & $4^{\text {th }}$ \\
\hline
\end{tabular}

Table 5: Mean and Standard Deviation and Rank Order Analysis of Students' Perception on the Use of Field Trips as a Supplementary Method of Teaching and Learning of Business Studies Source: Field Study, 2016

Table 4 and 5 above assessed teachers' and students' perception separately on the use of field trips as a supplementary method of teaching and learning of business studies. Both individual assessment goes in line with their collective assessment which agrees with items 3 and 2 "the use of field trips in the process of teaching and learning of business studies improve academic performance of the students" and "economic background of the students has an adverse effect on the use of field trips as supplementary method of teaching business studies". While they both disagreed with items 7th and 6thwhich states that "students have negative attitude towards the use of field trips as supplementary method of teaching business studies" and that "there is no adequate support from the principals of the school in using field trips as a supplementary method of teaching business studies".

\begin{tabular}{|c|c|c|c|c|c|c|c|}
\hline \multirow[t]{2}{*}{ Year } & \multirow[t]{2}{*}{ Status } & \multicolumn{5}{|c|}{ GRADES } & \multirow[t]{2}{*}{ Total } \\
\hline & & $\mathbf{A}$ & B & C & $\mathbf{P}$ & $\mathbf{F}$ & \\
\hline \multirow[t]{3}{*}{2012} & Utilize Field Trips & $\begin{array}{c}29 \\
36.2 \%\end{array}$ & $\begin{array}{c}10 \\
12.5 \%\end{array}$ & $\begin{array}{c}27 \\
33.8 \%\end{array}$ & $\begin{array}{c}9 \\
11.2 \%\end{array}$ & $\begin{array}{c}5 \\
6.2 \%\end{array}$ & $\begin{array}{c}80 \\
100.0 \%\end{array}$ \\
\hline & $\begin{array}{c}\text { Without Field } \\
\text { Trips }\end{array}$ & $\begin{array}{c}2 \\
2.5 \%\end{array}$ & $\begin{array}{c}5 \\
6.2 \%\end{array}$ & $\begin{array}{c}21 \\
26.2 \%\end{array}$ & $\begin{array}{c}35 \\
43.8 \%\end{array}$ & $\begin{array}{c}17 \\
21.2 \%\end{array}$ & $\begin{array}{c}80 \\
100.0 \%\end{array}$ \\
\hline & Total & $\begin{array}{c}31 \\
19.4 \% \\
\end{array}$ & $\begin{array}{c}15 \\
9.4 \% \\
\end{array}$ & $\begin{array}{c}48 \\
30.0 \% \\
\end{array}$ & $\begin{array}{c}44 \\
27.5 \% \\
\end{array}$ & $\begin{array}{c}22 \\
13.8 \% \\
\end{array}$ & $\begin{array}{c}160 \\
100.0 \% \\
\end{array}$ \\
\hline \multirow[t]{3}{*}{2013} & Utilize Field Trips & $\begin{array}{c}23 \\
28.8 \%\end{array}$ & $\begin{array}{c}18 \\
22.5 \%\end{array}$ & $\begin{array}{c}31 \\
38.8 \%\end{array}$ & $\begin{array}{c}8 \\
10.0 \%\end{array}$ & $\begin{array}{c}0 \\
0.0 \%\end{array}$ & $\begin{array}{c}80 \\
100.0 \%\end{array}$ \\
\hline & $\begin{array}{c}\text { Without Field } \\
\text { Trips }\end{array}$ & $\begin{array}{c}6 \\
7.5 \%\end{array}$ & $\begin{array}{c}1 \\
1.2 \%\end{array}$ & $\begin{array}{c}21 \\
26.2 \%\end{array}$ & $\begin{array}{c}31 \\
38.8 \%\end{array}$ & $\begin{array}{c}21 \\
26.2 \%\end{array}$ & $\begin{array}{c}80 \\
100.0 \%\end{array}$ \\
\hline & Total & $\begin{array}{c}29 \\
18.1 \%\end{array}$ & $\begin{array}{c}19 \\
11.9 \%\end{array}$ & $\begin{array}{c}52 \\
32.5 \% \\
\end{array}$ & $\begin{array}{c}39 \\
24.4 \%\end{array}$ & $\begin{array}{c}21 \\
13.1 \%\end{array}$ & $\begin{array}{c}160 \\
100.0 \%\end{array}$ \\
\hline \multirow[t]{3}{*}{2014} & Utilize Field Trips & $\begin{array}{c}36 \\
45.0 \%\end{array}$ & $\begin{array}{c}14 \\
17.5 \%\end{array}$ & $\begin{array}{c}24 \\
30.0 \%\end{array}$ & $\begin{array}{c}5 \\
6.2 \%\end{array}$ & $\begin{array}{c}1 \\
1.2 \%\end{array}$ & $\begin{array}{c}80 \\
100.0 \%\end{array}$ \\
\hline & $\begin{array}{c}\text { Without Field } \\
\text { Trips }\end{array}$ & $\begin{array}{c}2 \\
2.5 \%\end{array}$ & $\begin{array}{c}3 \\
3.8 \%\end{array}$ & $\begin{array}{c}17 \\
21.2 \%\end{array}$ & $\begin{array}{c}28 \\
35.0 \%\end{array}$ & $\begin{array}{c}30 \\
37.5 \%\end{array}$ & $\begin{array}{c}80 \\
100.0 \%\end{array}$ \\
\hline & Total & $\begin{array}{c}38 \\
23.8 \%\end{array}$ & $\begin{array}{c}17 \\
10.6 \%\end{array}$ & $\begin{array}{c}41 \\
25.6 \%\end{array}$ & $\begin{array}{c}33 \\
20.6 \%\end{array}$ & $\begin{array}{c}31 \\
19.4 \%\end{array}$ & $\begin{array}{c}160 \\
100.0 \%\end{array}$ \\
\hline
\end{tabular}

Table 6: Academic Performance of Students Who's Teachers Uses Field Trips to Complement Teaching of Business Studies and Those Students Who's Teachers Do Not Source: Field Study, 2016

Table 6 above shows the academic performance of schools (students) in JSS school certificate examination over a three-year period (2012-2014). The results were expressed based on schools with field trips and schools without field trips. It was observed that majority of the passes (A-C) were observed within schools with field trips, whereas majority of those with poor results (P \& F) are found within schools without field trips across the three-year period. 


\subsubsection{Research Question Three}

What is the difference between the academic performance of students whose teachers use field trips to complement their method of teaching business studies and those whose teachers do not?

\begin{tabular}{|c|c|c|c|c|c|c|c|}
\hline \multirow[b]{2}{*}{ Year } & \multirow[b]{2}{*}{ Status } & \multicolumn{5}{|c|}{ GRADES } & \multirow[b]{2}{*}{ Total } \\
\hline & & $\mathbf{A}$ & B & $\mathrm{C}$ & $\mathbf{P}$ & $\mathbf{F}$ & \\
\hline \multirow{3}{*}{2012} & Utilize Field Trips & $\begin{array}{c}29 \\
36.2 \%\end{array}$ & $\begin{array}{c}10 \\
12.5 \%\end{array}$ & $\begin{array}{c}27 \\
33.8 \%\end{array}$ & $\begin{array}{c}9 \\
11.2 \%\end{array}$ & $\begin{array}{c}5 \\
6.2 \%\end{array}$ & $\begin{array}{c}80 \\
100.0 \%\end{array}$ \\
\hline & $\begin{array}{l}\text { Without Field } \\
\text { Trips }\end{array}$ & $\begin{array}{c}2 \\
2.5 \%\end{array}$ & $\begin{array}{c}5 \\
6.2 \%\end{array}$ & $\begin{array}{c}21 \\
26.2 \%\end{array}$ & $\begin{array}{c}35 \\
43.8 \% \\
\end{array}$ & $\begin{array}{c}17 \\
21.2 \% \\
\end{array}$ & $\begin{array}{c}80 \\
100.0 \%\end{array}$ \\
\hline & Total & $\begin{array}{c}31 \\
19.4 \% \\
\end{array}$ & $\begin{array}{c}15 \\
9.4 \% \\
\end{array}$ & $\begin{array}{c}48 \\
30.0 \% \\
\end{array}$ & $\begin{array}{c}44 \\
27.5 \% \\
\end{array}$ & $\begin{array}{c}22 \\
13.8 \% \\
\end{array}$ & $\begin{array}{c}160 \\
100.0 \%\end{array}$ \\
\hline \multirow{3}{*}{2013} & Utilize Field Trips & $\begin{array}{c}23 \\
28.8 \%\end{array}$ & $\begin{array}{c}18 \\
22.5 \%\end{array}$ & $\begin{array}{c}31 \\
38.8 \%\end{array}$ & $\begin{array}{c}8 \\
10.0 \%\end{array}$ & $\begin{array}{c}0 \\
0.0 \%\end{array}$ & $\begin{array}{c}80 \\
100.0 \%\end{array}$ \\
\hline & $\begin{array}{c}\text { Without Field } \\
\text { Trips } \\
\end{array}$ & $\begin{array}{c}6 \\
7.5 \% \\
\end{array}$ & $\begin{array}{c}1 \\
1.2 \% \\
\end{array}$ & $\begin{array}{c}21 \\
26.2 \% \\
\end{array}$ & $\begin{array}{c}31 \\
38.8 \% \\
\end{array}$ & $\begin{array}{c}21 \\
26.2 \% \\
\end{array}$ & $\begin{array}{c}80 \\
100.0 \% \\
\end{array}$ \\
\hline & Total & $\begin{array}{c}29 \\
18.1 \% \\
\end{array}$ & $\begin{array}{c}19 \\
11.9 \% \\
\end{array}$ & $\begin{array}{c}52 \\
32.5 \% \\
\end{array}$ & $\begin{array}{c}39 \\
24.4 \% \\
\end{array}$ & $\begin{array}{c}21 \\
13.1 \% \\
\end{array}$ & $\begin{array}{c}160 \\
100.0 \%\end{array}$ \\
\hline \multirow{3}{*}{2014} & Utilize Field Trips & $\begin{array}{c}36 \\
45.0 \% \\
\end{array}$ & $\begin{array}{c}14 \\
17.5 \% \\
\end{array}$ & $\begin{array}{c}24 \\
30.0 \% \\
\end{array}$ & $\begin{array}{c}5 \\
6.2 \% \\
\end{array}$ & $\begin{array}{c}1 \\
1.2 \% \\
\end{array}$ & $\begin{array}{c}80 \\
100.0 \% \\
\end{array}$ \\
\hline & $\begin{array}{c}\text { Without Field } \\
\text { Trips } \\
\end{array}$ & $\begin{array}{c}2 \\
2.5 \% \\
\end{array}$ & $\begin{array}{c}3 \\
3.8 \% \\
\end{array}$ & $\begin{array}{c}17 \\
21.2 \% \\
\end{array}$ & $\begin{array}{c}28 \\
35.0 \% \\
\end{array}$ & $\begin{array}{c}30 \\
37.5 \% \\
\end{array}$ & $\begin{array}{c}80 \\
100.0 \%\end{array}$ \\
\hline & Total & $\begin{array}{c}38 \\
23.8 \% \\
\end{array}$ & $\begin{array}{c}17 \\
10.6 \% \\
\end{array}$ & $\begin{array}{c}41 \\
25.6 \% \\
\end{array}$ & $\begin{array}{c}33 \\
20.6 \% \\
\end{array}$ & $\begin{array}{c}31 \\
19.4 \%\end{array}$ & $\begin{array}{c}160 \\
100.0 \%\end{array}$ \\
\hline
\end{tabular}

Table 7: Academic Performance of Students who's Teachers Uses Field Trips to Complement Teaching of Business Studies and Those Students Who's Teachers Do Not Source: Field Study, 2016

Table 7 above shows the academic performance of schools (students) in JSS school certificate examination over a three-year period (2012-2014). The results were expressed based on schools with field trips and schools without field trips. It was observed that majority of the passes (A-C) were observed within schools with field trips, whereas majority of those with poor results (P \& F) are found within schools without field trips across the three-year period.

\subsubsection{Research Question Four}

How many schools do their business studies teachers use filed trips as a supplementary method in teaching and learning business studies?

\begin{tabular}{|c|c|c|c|}
\hline Field Trip Status & No of schools & Frequency & Percentage \\
\hline Utilize field trips & 4 & 88 & 50.0 \\
\hline Without field trips & 4 & 88 & 50.0 \\
\hline Total & 8 & 176 & 100 \\
\hline
\end{tabular}

Table 8: Field Trip Status of Number of Schools That Business Studies Teachers Use

Field Trips as a Supplementary Method in Teaching and Learning Business Studies

From the total sample of schools selected from population which is eight (8) secondary schools, four (4) schools utilizes field trips as supplementary method in teaching and learning business studies, while four (4) schools do not use field trips as a supplementary method in teaching and learning business studies.

\subsection{Test of Hypotheses}

The hypotheses were tested using t-test at 0.05 level of significant

\subsubsection{Hypothesis One}

The mean response of teachers and students have no influence on the effectiveness of using field trip exercise as a supplementary method of teaching and learning business studies.

\begin{tabular}{|c|c|c|c|c|c|c|c|}
\hline Status & N & Mean & Std. Dev. & t value & df & p value & Decision \\
\hline Student & 160 & 25.73 & 3.075 & \multirow{2}{*}{-2.060} & \multirow{2}{*}{174} & 0.041 & \multirow{2}{*}{ Rejected } \\
\hline Teacher & 16 & 27.38 & 2.680 & & & \\
\hline
\end{tabular}

Table 9: The T-Test Analysis of the Mean Response of Teachers and Students as Regards Field Trips Being an Effective Supplementary Method of Teaching and Learning Business Studies

Table 9. indicated that the t-test analysis to determine the difference in the opinion of students and teachers as regards field trips being an effective supplementary method of teaching and learning business studies. The result from the 
analysis indicated that teachers had better perception significantly over the students as regards field trips being an effective supplementary method of teaching and learning business studies because the table shows mean scores of 27.38 for the teachers and mean scores of 25.73 of the students. The calculated value of t-test statistics was -2.060 with 174 degree of freedom. The null hypothesis is therefore rejected. This simply shows that there is significant difference in the perception of teachers over the students as regards the field trips being an effective supplementary method of teaching and learning business studies.

\subsubsection{Hypothesis Two}

The mean response of students has no influence on field trip exercise as a supplementary method of teaching by those whose teachers use field trips and those whose teachers do not

\begin{tabular}{|c|c|c|c|c|c|c|c|}
\hline Status & $\mathbf{N}$ & Mean & Std. Dev. & t value & df & p value & Decision \\
\hline Utilize Field Trips & 80 & 56.51 & 5.454 & \multirow{2}{*}{-1.807} & \multirow{2}{*}{158} & \multirow{2}{*}{0.073} & \multirow{2}{*}{ Accepted } \\
\hline Without Field Trips & 80 & 58.16 & 6.081 & & & & \\
\hline
\end{tabular}

Table 10: The T-Test Analysis of the Mean Response of Students Who's Teachers Use Field

Trips and Those Who's Teachers Do Not Use Field Trips as A Supplementary Method of Teaching and Learning of Business Studies

Data presented in table 10 shows that the calculated value of t-test was -1.807 at degree of freedom (df) of 158 is not significant at $p$-value 0.073 . Since the p-value is greater than alpha value of 0.05 , the null hypothesis is retained. Hence, there is no significant difference in the mean response of students whose teachers use field trips as a supplementary method of teaching and learning of business studies and those whose teachers do not.

\section{Discussion of Findings}

In recent times, the performance in Business Studies has been on the decline; the results released by the Kwara State Ministry of Education from 2012-2014 showed that 20.8\% passed in 2012, 16.9\% in 2013 and 13.1\% in 2014. A lot of reasons could be responsible for this in Kwara state, lack of facilities, poor effective teaching and learning and improper classroom management. Although several teachers claimed to have tried several strategies to avert this trend there are have been many success stories. The adoption of Field Trip which as a strategy for teaching the subject has yielded some positive results with assertions that it does not only influence the cognitive and psychomotor domains of the learners but has a lot to do the affective domain of the learner. Hence, this study was designed to determine the influence of field trip on the effective teaching and learning of business studies in Junior Secondary School in Offa and Oyun Local Government Area of Kwara State.

The results showed that students and teachers are of the opinion that the use of field trips as supplementary method of teaching will enhance the effective teaching and learning of business studies in Junior Secondary Schools in Offa and Oyun Local Government Area of Kwara State. This was shown in their consensus opinions that "the use of field trips as supplementary method of teaching business studies motivates learners"; also "the use of field trips as complementary method of teaching business studies allow the students to fully participate in the process of teaching and learning" and that "the use of field trips added more knowledge to and thereby enhance effective teaching and learning". This observation is in accordance with the assertion by Aliyu (2008) who perceives field trips as an alternative method of teaching which supplement and complement the critical classroom teaching in schools.

Also, students and teachers of Junior Secondary Schools in Offa and Oyun Local Government Area of Kwara State are of the strong perception that "the use of field trips in the process of teaching and learning of business studies improve academic performance of the students" and "economic background of the students has an adverse effect on the use of field trips as supplementary method of teaching business studies". This observation underlines the essence of this study as regard the importance of field trips in the teaching and learning of Business Studies. This finding is complemented further by comparing the results from schools who partake in field trips as part of teaching and learning of Business Studies and Schools who do not. Results of the comparisons, using JSS school certificate examination over a three-year period (20122014), showed that majority of the passes (A-C) were observed within schools with field trips, whereas majority of those with poor results (P \& F) are found within schools without field trips across the three-year period. It was also observed that schools with field trips had significantly higher mean performance scores than their counterpart without field trips. This agrees to the findings Mishia (2007) who observed that classes that used the planned field trip technique learned more, retained more and did better on tests than the classes not participating in field trips. This further complements the initial assertion of the impact of field trips on academic performance of students in Business Studies. Although previous researches in an area in Lagos by Uvulor (2000) observed no significant difference in the performance of students with or without field trips, this could be due to nature of sample recruitment. He recruited less than 30 students from just two school in a locality. This study recruited 180 students and 20 teachers from schools randomly selected which allows for more accurate and reliable results.

Results obtained from this study was similar to those Abeku (2006) and Yusuf (2006). Abeku (2006) observed that field trips added to the classroom teaching increase the understanding and the performance of the students in Agricultural science in post-primary school of Akwanga Area of Nasarawa State. Also, it motivates the students to implore in the academic and boost morale of the students concern in the study. Yusuf (2006), on the other hand, showed that students taught using field trips performed significantly better than their counterpart taught using the conversional method without complementary field trips method in Ilorin metropolis. 
It was also observed from the study that teachers had better perception over the students as regards field trips being an effective supplementary method of teaching and learning business studies. This complements recommendations from Yusuf (2006), who based on these findings advised that teachers of social studies should expose students to field trips as this will promote learning experience, discovery learning, active engagement in learning and self -motivation in social studies. Teachers should have better understanding of the impact of excursions or field trips as complementary and supplementary means for stimulating the domains of learning in students.

\section{Recommendations}

Based on the findings from this study the following recommendations are hereby presented

- Teachers of Secondary Schools should be encouraged to use Field Trips as Instructional Resources to enhance the effective Teaching and Learning of Business Studies. Teaching time table should be planned by the school authorities such that they make room for the organization of field trips.

- The Teacher education programme should be geared towards the preparation of business studies teachers that will enable them to acquire and maintain appropriate instructional strategy which could be needed after training and which will promote effective teaching and learning.

- Curriculum planners should formulate policies on Field Trips in the teaching of Business Studies, so that the decision to utilize Field Trips as an Instructional Resource is not left to the personal discretion of any single individual.

- Government through the Ministry of Education should set aside funds to support the arrangement of Field Trips to enhance effective teaching and learning. Hence Education planners should develop instruction that will bring about development and acquisition of critical thinking, problem solving and performance skills in students.

- Parents should be educated on the influence of Field Trips as a supplementary method in teaching and learning of business studies in order to expose students to field Trips which will promote and encourage social interaction, active engagement in learning, self-motivation, discovery learning by doing and learning by experience.

\section{References}

i. Abeku, N. A. (2006), Factors that influence learning during a scientific field trip in a natural environment. Journal of Research in Science Teaching, 31 (10) 1097-1119.

ii. Abimbola, I. O. \& Abolade, A. 0. (2004), Fundamental Principles and Practice of Instruction. Tunde Babs Printers, Ilorin. 48-51

iii. Aliyu, M. M. (2008), Educational Excursion and Students' Achievement in Business Studies. Journal of Educational Research Development, Faculty of Education A.B.U Zaria Vol.3 (No 2) 112-113.

iv. Casady, J. (2008), Electronic field trips as interactive learning events: promoting students learning at a distance. Journal of Interactive Learning Research, 36(9), 564-573.

v. Colonial Williamsburg (1999), Towards a Virtual Field Trip Model for the Social Studies contemporary issue in technology and teacher education, 9(4), 412-438.

vi. Jekayinfa, A. A. (2005), Fundamentals of Instructional Method. Ilorin: Olives production Ltd. 88-94.

vii. Mills, H.R (1990), Teaching and Training. A Handbook for Instructions. The Macmillan Press Ltd. London. 78-91

viii. Pandey S. K \& Sharma R. S (2009). Resources of Effective Teaching. Commonwealth Publishers, New Delhi 11002.79

ix. Uzoma, R. C. (1994) An Investigation into the extent to which Field Trips are Employed in Geography in Secondary schools in Imo State Nigeria. Unpublished Bachelor's Degree Thesis. University of Nigeria, Nsukka 43-49

x. Vanderstel, S. (2002). Zoos as a source of free choice learning. Research in Science and Technological Education $2167-99$.

xi. Web, (2010) Wikipedia, The Free Encyclopedia. Field Trip miracle for teachers. Retained on 29 July, 2014. 